\title{
Note on the Notes
}

Sources are cited in the notes in a short form, which should identify most of them to anyone familiar with the literature and the abbreviations that follow. Full bibliographical citations to all articles and books-though not to editorials in journals or to interventions at scientific meetings-appear in the Bibliography. All references to unpublished materials include the archive code except for the Ernest $\mathrm{O}$. Lawrence Papers, which are identified by the form $(\mathrm{x} / \mathrm{y})$, where $\mathrm{x}$ refers to box and $\mathrm{y}$ to folder.

Abbreviations used in the notes:

\begin{tabular}{|c|c|}
\hline AHQP & Archive for the History of Quantum Physics \\
\hline AIP & American Institute of Physics \\
\hline$A J P$ & American journal of physics \\
\hline Alvarez $\mathrm{P}$ & $\begin{array}{l}\text { Luis Alvarez Papers, Lawrence Berkeley Labora- } \\
\text { tory }\end{array}$ \\
\hline APhils & American Philosophical Society \\
\hline APS & American Physical Society \\
\hline BAAS & British Association for the Advancement of Science \\
\hline$B A S$ & Bulletin of the atomic scientists \\
\hline Barrett P & $\begin{array}{l}\text { E.C. Barrett Papers, California Institute of Tech- } \\
\text { nology }\end{array}$ \\
\hline BSC & Niels Bohr Scientific Correspondence, in AHQP \\
\hline Birge & $\begin{array}{l}\text { Birge, R.T. History of the physics department. } \\
\text { Typescript. } 5 \text { vols. Berkeley, 1966-. }\end{array}$ \\
\hline Birge $\mathbf{P}$ & R.T. Birge Papers, TBL \\
\hline Bretscher $\mathrm{P}$ & $\begin{array}{l}\text { Egon Bretscher Papers, Churchill College, Cam- } \\
\text { bridge }\end{array}$ \\
\hline$F$ & The Chemical Foundation \\
\hline CIW & Carnegie Institution, Washington \\
\hline
\end{tabular}


xxiv / NOTE ON THE NOTES

CKFT John Cockcroft Papers, Churchill College, Cambridge

$C P \quad$ Collected papers, identified by author

$C R$

Académie des Sciences, Paris, Comptes rendus

Crowther Crowther, J.G. The Cavendish Laboratory, 18741974. New York: Science History Publications, 1974.

CW Collected works, identified by author

ER Ernest Rutherford Papers, AHQP

Eve Eve, A.S. Rutherford. New York: Macmillan, 1939.

FAL F.A. Lindemann (Lord Cherwell) Papers, Nuffield College, Oxford

Fermi P Enrico Fermi Papers, University of Chicago Library, Chicago

Flexner P Simon Flexner Papers, American Philosophical Society

Frisch P O.R. Frisch Papers, UA

Geiger Geiger, Roger L. To advance knowledge. The growth of American research universities, 19001940 Oxford: Oxford University Press, 1986.

GPT G.P. Thomson Papers, Trinity College, Cambridge, courtesy of the Master and Fellows

HAB H.A. Bethe Papers, Cornell University Library

Hale P G.E. Hale Papers, California Institute of Technology

Hartcup \& Allibone

Hartcup, Guy, and T.E. Allibone. Cockcroft and the atom. Bristol: Adam Hilger, 1984.

Harteck P Paul Harteck Papers, Rensselaer Polytechnic Institute, Archives and Special Collections, Troy, New York

Hendry Hendry, John, ed. Cambridge physics in the thirties. Bristol: Adam Hilger, 1984.

HSPS Historical studies in the physical and biological sciences

ICHS International Congress of History of Science

IEEE Institute of Electrical and Electronics Engineers

IRE Institute of Radio Engineers 


\begin{tabular}{|c|c|}
\hline$J A C S$ & American Chemical Society, Journal \\
\hline$J F I$ & Franklin Institute, Journal \\
\hline JP & Frédéric Joliot Papers, Institut du Radium, Paris \\
\hline$J P$ & Journal de physique \\
\hline Kamen & $\begin{array}{l}\text { Kamen, Martin. Radiant science, dark politics. } \\
\text { Berkeley: University of California Press, } 1985 .\end{array}$ \\
\hline evles & $\begin{array}{l}\text { Kevles, Daniel J. The physicists. The history of a } \\
\text { scientific community in modern America. New } \\
\text { York: Knopf, } 1978 \text {. }\end{array}$ \\
\hline TC & $\begin{array}{l}\text { MIT, Office of the President, } 1930-1958 \\
\text { (Compton-Killian), (AC4) Institute Archives and } \\
\text { Special Collections, MIT Libraries, Cambridge, } \\
\text { Massachusettes. }\end{array}$ \\
\hline angevin $\mathrm{P}$ & $\begin{array}{l}\text { Paul Langevin Papers, Ecole municipale de chimie } \\
\text { et physique industrielles, Paris }\end{array}$ \\
\hline aurit & $\begin{array}{l}\text { C.C. Lauritsen Papers, California Institute of Tech- } \\
\text { nology }\end{array}$ \\
\hline ewis & G.N. Lewis Papers, TBL \\
\hline iving & $\begin{array}{l}\text { Livingston, M.S., ed. The devel } \\
\text { energy accelerators. New York: Do }\end{array}$ \\
\hline $\operatorname{vir}$ & \\
\hline ewe & $\begin{array}{l}\text { Livingston, M.S., and J.P. Blewett. Particle } \\
\text { accelerators. New York: McGraw-Hill, } 1962 .\end{array}$ \\
\hline eeb P & Leonard Loeb Papers, TBL \\
\hline MAT & M.A. Tuve Papers, Library of Congress \\
\hline Mendelssohn & Kurt Mendelssohn Papers, Bodleian Library, \\
\hline IcMillan P & $\begin{array}{l}\text { E.M. McMillan Papers, Lawrence Berkeley Labora- } \\
\text { tory }\end{array}$ \\
\hline Millikan P & $\begin{array}{l}\text { R.A. Millikan Papers, California Institute of Tech- } \\
\text { nology }\end{array}$ \\
\hline MPG & Archives, Max-Planck-Gesellschaft, Berlin \\
\hline Nahmias & $\begin{array}{l}\text { Nahmias, Maurice E. Machines atomiques. Paris: } \\
\text { Editions de la Revue d'Optique, } 1950 . \text { Mrs. } \\
\text { Bretscher Papers kept by Mrs Egon Bretscher, } \\
\text { Cambridge, England. }\end{array}$ \\
\hline & National Academy of Sc \\
\hline 0 & John Francis Neylan Pa \\
\hline
\end{tabular}


Nobel Protokoll ang. Nobelärenden, Royal Swedish Academy of Sciences, Stockholm

NRC National Research Council

Nwn Die Naturwissenschaften

Pegram P George B. Pegram Papers, Rare Book and Manuscript Library, Columbia University, New York City

$P R \quad$ Physical review

PRS Royal Society of London, Proceedings

PT Physics today

RC Research Corporation Archives, New York City

Reingold Reingold, Nathan, ed. The sciences in the American context. Washington, D.C.: Smithsonian Institution, 1979.

RF Rockefeller Foundation Archives, North Tarrytown, New York

Richardson P O.W. Richardson Papers, Harry Ransom Humanities Reseach Center, The University of Texas at Austin

RMP Review of modern physics

$R S I$

Review of scientific instruments

SEBM

Society for Experimental biology and medicine

Seidel

Seidel, Robert $W$. Physics research in California:

The rise of a leading sector in American physics. Ph.D. thesis, University of California, Berkeley, 1978. (DAI, 7904599.)

Swann P W.F.G. Swann Papers, APS

SzP Leo Szilard Papers, University of California, San Diego

TBL The Bancroft Library, University of California, Berkeley

UA Cambridge University Archives

UAV Harvard University Archives

UCA Archives, University of California, Berkeley

UCPF President's files, University of California

Urey P Harold Urey Papers, University of California, San Diego 
Weart

Weart \&

Phillips

Weart \&

Szilard
Weart, Spencer Scientists in power. Cambridge, MA: Harvard University Press, 1979.

Weart, Spencer, and Melba Phillips, eds. History of physics. Readings from Physics today. New York: American Institute of Physics, 1985.

Weart, Spencer, and Gertrud Weiss Szilard, eds. Leo Szilard: His version of the facts. Selected recollections and correspondence. Cambridge, MA: MIT Press, 1978. 
